\title{
PREVALENCE OF NEWCASTLE DISEASE VIRUS IN BROILER CHICKENS (Gallus gallus) IN BRAZIL
}

\section{Orsi, M.A. ${ }^{1,2}$; Doretto Jr, L. ${ }^{3}$; Camillo, S.C.A. ${ }^{1}$; Reischak, D. ${ }^{1}$; Ribeiro, S.A.M. ${ }^{1}$; Ramazzoti, A. ${ }^{1}$; Mendonça, A.O. ${ }^{1}$;} Spilki, F.R. ${ }^{4}$; Buzinaro, M.G. ${ }^{5}$; Ferreira, H.L. ${ }^{6}$; Arns, C.W. ${ }^{2,6^{*}}$

${ }^{1}$ Laboratório Nacional Agropecuário, Ministério da Agricultura, Pecuária e Abastecimento, Campinas, SP, Brasil; ${ }^{2}$ Faculdade de Ciências Médicas, Universidade Estadual de Campinas, Campinas, SP, Brasil; ${ }^{3}$ Centro Brasileiro de Pesquisa Animal, Amparo, SP, Brasil; ${ }^{4}$ Instituto de Ciências da Saúde, Centro Universitário Feevale, Novo Hamburgo, RS, Brasil; ${ }^{5}$ Departamento de Medicina Veterinária Preventiva e Reprodução Animal, Faculdade de Ciências Agrárias e Veterinárias, Universidade Estadual Paulista, Jaboticabal, SP, Brasil ${ }^{6 *}$ Laboratório de Virologia, Instituto de Biologia, Universidade Estadual de Campinas, Campinas,

$$
\text { SP, Brasil. }
$$

Submitted: June 06, 2009; Returned to authors for corrections: July 23, 2009; Approved: February 17, 2010.

\begin{abstract}
This study was carried out during 2002/2003, aiming to determine the prevalence of virulent Newcastle disease virus strains (NDV) in Brazilian commercial poultry farms. Clinical samples were obtained from the Southeastern, Southern and Central-Western regions, which comprise the main area of the Brazilian poultry production. Serum samples and tracheal and cloacal swabs of 23,745 broiler chickens from 1,583 flocks, including both vaccinated chickens and those with no vaccination information, were tested for NDV using a diagnostic ELISA kit. The seropositivity was $39.1 \%$, and the isolation percentage by flock varied from 1.0 to $7.6 \%$, and by region from 6.5 to $58.4 \%$. Higher isolation rates $(74.3-83.3 \%)$ were obtained after three passages in embryonated chicken eggs. All isolates preliminarily identified as NDV were characterized as nonpathogenic strains, as their Intracerebral Pathogenicity Index (ICPI) was below 0.7. Based on results of this study, Brazil can claim a virulent NDV-free status for commercial flocks.
\end{abstract}

Key words: Newcastle Disease Virus, NDV-free status, pathogenicity, broiler chickens, biological characterization.

\section{INTRODUCTION}

Avian paramyxovirus-1 (APMV-1), the causative agent of the Newcastle Disease (NDV), is classified as a member of genus Avulavirus in the family Paramyxoviridae $(14,15)$. Newcastle disease (ND), one of the most important viral diseases in industrial aviculture (3), affects domestic poultry and wild birds and may cause acute mortality marked by hemorrhagic lesions, respiratory and apparent or unapparent enteric infections, among others. Therefore, the etiopathogenic diagnosis should be conventionally based on isolation and biological characterization of field samples (29).

NDV detection and pathotyping of avian isolates are extremely important because the appearance of virulent virus has significant economic consequences related to vaccination and eradication, impairing the ability of a given geographic region to export poultry products (24).

The widespread presence of lentogenic strains in feral

*Corresponding Author. Mailing address: Laboratory of Virology, Institute of Biology, State University of Campinas, CP 6109, 13083-970, Campinas, SP, Brazil.; Tel.: +55 1935216267 Fax: +55 19 35216185.; E-mail: $\underline{\text { arns@ @nicamp.br }}$ 
birds and the use of such viruses as live vaccines mean that isolation of NDV is not enough to confirm a disease diagnosis and compliance with statutory requirements that may be in place (8). Viral characterization using the pathogenicity test or nucleotide sequencing are also required, as the importance and impact of a given NDV isolate are directly related to its virulence. Once analysis of a given field disease solely may be an unreliable measurement of pathogenicity due to the possibility of concurrent infections and bad technical management, laboratory assessments of the virus pathogenicity are necessary. For this purpose, currently three "in vivo" tests are available, which include determination of ICPI (Intracerebral Pathogenicity Index), IVPI (Intravenous Pathogenicity Index) and MDT (Mean Death Time) (3).

The World Organisation for Animal Health (OIE) is recognized by the World Trade Organization for standardization of matters related to animal health that may affect international trade. NDV infection is defined as a notifiable disease if the virus in day-old chick (Gallus gallus) has ICPI of 0.7 or above, or contains certain multiple basic amino acids at the fusion (F) protein cleavage site (19). APMV-1 that does not meet the OIE definition for causing ND is referred to as a low-virulence APMV-1 or NDV.

The first description of this disease in Brazil occurred in Belém and Macapá in 1953, (22). The outbreak was a consequence of the importation of NDV-contaminated frozen chicken carcasses from the United States (28). The first NDV isolation in Brazil was accomplished by Cunha and Silva (10). This NDV strain has been designated as M33 and its biological characterization was performed by Oliveira et al. (20). After the first impact in the 1950's decade, the Newcastle disease, although endemic, has been seen only sporadically, attacking breeding stocks of small economic expression. Outbreaks have been quickly controlled by vaccination and complementary prophylactic measures.

Poultry is the Brazilian leading export product in the meat sector. The performance of this sector in 2006 consolidated Brazil in the first-position, conquered in 2004, as the world's biggest exporter both in volume and revenue. Behind the soybean complex, poultry ranks second in the Brazilian agribusiness exporting rank (2).

The broiler chicken production in the country is concentrated in the Southern and Southeastern regions (1), where the main producers and exporters of genetic material from chickens are located. Lately the Central-Western region has also experienced a significant expansion.

The nationwide poultry production efficiency makes Brazil a competitive nation in international markets, even in the absence of economic subsidies. Aiming to guarantee better sanitary conditions to Brazilian avian products, an epidemiological project, in agreement with the National Program for Poultry Sanity (PNSA), was implemented for the control of Newcastle Disease in the country.

This study evaluated the prevalence of Newcastle Disease in commercial birds in poultry producing areas in Brazil and the occurrence of the virus in this aviary segment. When pathogenic viruses are absent, the country can be declared free of virulent Newcastle Disease.

\section{MATERIALS AND METHODS}

\section{Sample calculation and source}

Samples were collected weekly from apparently healthy birds in by official service, in slaughterhouses located in selected areas of nine states of the Southeastern, Southern and Central-Western states. Blood serum of 15 birds per flock and pools of eight cloacal swabs and eight trachea swabs were placed separately in a buffered saline solution (PBS), with antibiotics $(10,000 \mathrm{U} / \mathrm{ml}$ penicillin, $10 \mathrm{mg} / \mathrm{ml}$ streptomycin, $0.25 \mathrm{mg} / \mathrm{ml}$ gentamicin and 5,000 IU/ml nystatin), adjusted to pH 7.0-7.4, and cold-stored .

Collected samples were sent to a screening centre in each state to ensure analysis viability, and insertion of data into a computerized information system. The material was sealed up and sent in the thermal ice boxes to the National Agricultural Laboratory (Lanagro/SP) in Campinas, São Paulo, Brazil. 
The calculation of the number of samples for the study was based on the total population of birds in each federative state, from a total of $410,729,182$ birds in the country, estimated by the Brazilian Ministry of Agriculture. Federative states were selected based on their importance for the Brazilian poultry industry, and comprised three regions: Southeastern (Minas Gerais and São Paulo states) Southern (Paraná, Santa Catarina and Rio Grande do Sul states) and Central Western (Goiás, Distrito Federal, Mato Grosso and Mato Grosso do Sul states).

Assuming a prevalence of at least $1 \%$ and a sensitivity of $99 \%$ for the detection of at least one infected flock, a minimum of 485 flocks were planned to be analyzed per region. The determination of the number of birds to be sampled by flock took into account the $95 \%$ sensitivity of the diagnostic test (ELISA), with an expected minimum prevalence of $30 \%$ of infected flocks, with confidence degree of $99 \%$, resulting in 15 chickens per flock.

The number of samples in each region was calculated using the following formula:

[1- (1-C) 1/ (D*SENS)]* [M- (/2 D*SENS-1)], where:

$$
\begin{aligned}
& \mathrm{C}=\text { reliability degree } \\
& \mathrm{M}=\mathrm{n} . \text { of units (animal/flocks) at risk } \\
& \mathrm{D}=\mathrm{n} . \text { of ill/infected units } \\
& \text { SENS = sensitivity test }
\end{aligned}
$$

The calculated number of samples was 23,745 broiler chickens (1,583 flocks) being 8,880 birds from 592 farms of the Southeastern region, 7,530 birds from 502 farms in the Southern region and 7,335 birds from 489 farms in the CentralWestern region. This project was carried out during 2002/2003, and the period of sample receipt was April $10^{\text {th }}$ to December $30^{\text {th }} 2002$.

An epidemiological enquiry was performed in all regions where the viral isolation was made, including the identification of counties and their properties. An epidemiological survey was conducted in each positive case to determine the possible sources of NDV isolates.

\section{Detection of NDV antibodies}

Chicken serum samples were diluted 1:500 and examined for NDV antibodies by indirect enzyme-linked immunosorbent assay (ELISA), using a commercial ELISA test kit (Flockscreen - Guildhay Laboratories Inc., Guilford, England), run in 96-well microtiter plates containing NDV antigen. The ELISA test was performed according to the manufacturer's recommendations. When at least one bird from a flock was ELISA positive, the whole flock was considered positive.

\section{Virus isolation}

Cloacal and tracheal swabs from all ELISA seropositive birds and from $2.5 \%$ of the seronegative flocks were submitted to viral isolation. The swabs, stored in transport media composed of phosphate-buffered saline solution (PBS) containing antibiotics, were sent to the National Agricultural Laboratory (Lanagro/SP), Campinas, São Paulo within 48 hrs after collection, in a refrigerated container $\left(2-8^{\circ} \mathrm{C}\right)$. In the laboratory the samples were stored at $-80^{\circ} \mathrm{C}$ until analyzed. The swabs were pooled and inoculated into five specificpathogen-free embryonated chicken eggs (9-11 days old), and processed according to standard NDV isolation procedures described by the Regulation \#182/94 of the Brazilian Ministry of Agriculture (5). The samples were submitted to three trials in embryonated chicken eggs, before considered negative.

Haemagglunation (HA) and haemagglutination inhibition (HI) tests were carried out according to the technique described in the Regulation \# 182/94 of the Brazilian Ministry of Agriculture (5).

\section{Viral identification}

NDV was determined using reference antisera APMV-1 to APMV9 by haemagglutination inhibition (HI) test, carried out according to Allan et al (4) and Regulation \# 182/94 of the Brazilian Ministry of Agriculture (5). As APMV-5 does not produce haemagglutination, this antiserum was not used in the analyses. The antisera were produced and kindly provided by the Veterinary Laboratory Agency - VLA, located in Weighbridge, Surrey, United Kingdom. 


\section{Biological characterization}

The pathogenicity of the NDV isolates was determined by measurement of the Intracerebral Pathogenicity Index (ICPI), as described in the Regulation \# 182/94 (5). According to the World Organisation for Animal Health (OIE), an IPIC $\geq 0.70$ indicates that NDV is pathogenic.

\section{Statistical analysis}

Statistical analysis was performed using the Chi-square test or Fisher's exact test $(11,23)$, Differences were considered statistically significant when $\mathrm{p} \leq 0.05$.

\section{RESULTS}

The highest prevalence of seropositive samples occurred in Southeastern region $(66.4 \%)$, followed by Central Western $(23.3 \%)$ and Southern $(22.3 \%)$ regions. In the country, the prevalence was $39.1 \%$. The seropositivity and frequency of virus isolation results are shown in Table 1. There was a significant difference in the percentage of seropositive samples in the three regions $(\mathrm{p}=0.0001)$. The average percentage of isolation per flock was $4.9 \%$, being $7.6 \%$ in the Southeastern region, $5.4 \%$ in the Southern region and $1.0 \%$ in the CentralWestern region. The Southeastern region presented the highest percentage when compared to the other regions. Considering the total number of isolates, $58.4 \%$ of the flocks were from the Southeastern region, followed by $35.1 \%$ in Southern region and $6.5 \%$ in the Central-Western region.

The number of passages in embryonated eggs required for isolation of NDV is shown in Tables 2 and 3. The isolation percentage in each passage in relation to the total samples is summarized in Table 2, showing that $14.3 \%$ of the samples were positive in the $1^{\text {st }}$ passage, $6.5 \%$ in the $2^{\text {nd }}$ passage and $79.2 \%$ in the $3^{\text {rd }}$ passage. The isolation percentage in each passage of vaccinated birds in relation to total isolates is presented in Table 3 , showing $9.5 \%$ positivity in $1^{\text {st }}$ passage, $7.1 \%$ in $2^{\text {nd }}$ passage and $83.3 \%$ in $3^{\text {rd }}$ passage. The isolation percentages from flocks with no information on vaccinal status, in relation to total isolates, were as follows: $20 \%$ positivity in $1^{\text {st }}$ passage, $5.7 \%$ in $2^{\text {nd }}$ passage and $74.3 \%$ in $3^{\text {rd }}$ passage. There was no significant difference in the percentage of isolation by vaccinal status $(\mathrm{p}=0.4793)$.

Table 1. Relationship between seropositivity and NDV isolation

\begin{tabular}{|c|c|c|c|c|c|}
\hline \multirow[b]{2}{*}{ Region } & \multirow{2}{*}{$\begin{array}{c}\text { Flocks } \\
\text { (n) }\end{array}$} & \multirow{2}{*}{$\begin{array}{c}\text { ELISA Seropositive* } \\
\text { flocks \% }\end{array}$} & \multicolumn{3}{|c|}{ Isolation } \\
\hline & & & (n) & $\begin{array}{c}\text { Flocks } \\
\%\end{array}$ & $\begin{array}{c}\text { Region } \\
\%\end{array}$ \\
\hline Southeastern & 592 & $393(66.4)^{*}$ & 45 & 7.6 & 58.4 \\
\hline Southern & 502 & $112(22.3)$ & 27 & 5.4 & 35.1 \\
\hline Central-Western & 489 & $114(23.3)$ & 05 & 1.0 & 6.5 \\
\hline TOTAL & 1.583 & $619(39.1)$ & 77 & 4.9 & 100.0 \\
\hline
\end{tabular}

* The percentage of seropositive flocks in the Southeastern region was significantly higher than that in the two other regions

Table 2. NDV isolates in each passage in embryonated chicken eggs (SPF) in relation to the total number of samples

\begin{tabular}{ccc}
\hline & \multicolumn{2}{c}{ NDV Isolates } \\
\cline { 2 - 3 } Passage & $\mathbf{N}$ & $\%$ \\
\hline $1^{\text {st }}$ & 11 & 14.3 \\
$2^{\text {nd }}$ & 05 & 6.5 \\
$3^{\text {rd }}$ & 61 & 79.2 \\
Positive & 77 & 100.0 \\
\hline
\end{tabular}


Table 3. NDV isolates by passages in embryonated chicken eggs, according to vaccination

\begin{tabular}{|c|c|c|c|c|}
\hline \multirow[t]{2}{*}{ Passages } & \multicolumn{2}{|c|}{ NDV isolates (n)* } & \multicolumn{2}{|c|}{$\begin{array}{c}\text { Isolation / Total } \\
\end{array}$} \\
\hline & Vaccinated & Not informed & $\%$ vaccinated & $\begin{array}{c}\text { \% Not } \\
\text { informed }\end{array}$ \\
\hline $1^{\text {st }}$ & 4 & 7 & 9.5 & 20.0 \\
\hline $2^{\text {nd }}$ & 3 & 2 & 7.1 & 5.7 \\
\hline $3^{\text {rd }}$ & 35 & 26 & 83.3 & 74.3 \\
\hline Total & 42 & 35 & 100.0 & 100.0 \\
\hline
\end{tabular}

The state with highest viral isolation percentage per flock was São Paulo (8.8\%), followed by Paraná (7.9\%), Minas Gerais $(5.3 \%)$, Santa Catarina $(4.7 \%)$, Rio Grande do Sul (2.8\%), Mato Grosso do Sul (1.8\%) and Mato Grosso (1.0\%). Among isolates, $44.2 \%$ were from São Paulo state, $19.5 \%$ from Paraná, $14.3 \%$ from Minas Gerais state, $10.4 \%$ from Santa Catarina, 5.2\% from Rio Grande do Sul and Mato Grosso do Sul, and $1.3 \%$ from Mato Grosso. As shown in Table 6, no virus isolation was obtained in the Federal District and state of Goiás. Figure 1 shows the isolation of NDV by geographic region.

In the pathogenicity characterization of NDV isolates (Table 4), the ICPI ranged between 0 and 0.66 . In $41.5 \%$ of the NDV isolates, ICPI varied from 0 to 0.10 , in $35.1 \%$ varied from 0.11 to 0.30 , in $18.2 \%$ varied from 0.31 to 0.50 and in $5.2 \%$ varied from 0.51 to 0.66 . These data indicate that none of the isolates was pathogenic, as their ICPI was lower than 0.70. The correlation between ICPI and samples region was not significant $(\mathrm{p}=0.6792)$, nor was significant the correlation between ICPI and birds vaccination status.

The grouping of the viruses by ICPI and region is shown in the Table 5. ICPI of vaccine strains are also shown in this table, for comparison. The $1^{\text {st }}$ group, with $41.5 \%$ isolates, presented ICPI between 0 and 0.10 , similar to vaccinal strains Ulster, VG-GA and V4. The isolates in the $1^{\text {st }}$ group were mainly in the Southeastern regions $(68.7 \%)$, followed by the Southern $(25 \%)$ and Central-Western $(6.3 \%)$ regions. The $2^{\text {nd }}$ group, represented by B1 vaccinal strain (ICPI from 0.11 to 0.30 ), comprised $35.1 \%$ of NDV isolates, being $46.1 \%$ in the Southeastern region, $44.4 \%$ in the Southern region and $7.4 \%$ in the Central-Western region. In the $3^{\text {rd }}$ group, represented by the La Sota and Clone 30 vaccinal strains. comprised $18.2 \%$ of isolates (ICPI from 0.31 to 0.50 ), being $50 \%$ in the Southeastern region, $42,9 \%$ in the Southern region and $7.1 \%$ in the Central-Western region. The $4^{\text {th }}$ group, with no vaccine strain used in Brazil, comprised 5.2\% of isolates (ICPI from 0.51 to 0.66 ), being $75 \%$ in the Southeastern region and $25 \%$ in the Southern region.

Table 4. Biological characterization of NDV

\begin{tabular}{cccc}
\hline Region & $\begin{array}{c}\text { Vaccination } \\
\text { status }\end{array}$ & $\begin{array}{c}\text { Number of } \\
\text { isolates }\end{array}$ & Range of ICPI \\
\hline Southeastern & + & 20 & $0-0.1$ \\
& + & 12 & $0.11-0.30$ \\
Southeastern & + & 07 & $0.31-0.50$ \\
& + & 03 & $0.51-0.66$ \\
Southern & - & 02 & $0-0.1$ \\
& - & 01 & $0.11-0.30$ \\
& - & 08 & $0-0.1$ \\
Central-Western & - & 12 & $0.11-0.30$ \\
& - & 06 & $0.31-0.50$ \\
& - & 01 & $0.51-0.66$ \\
& - & 02 & $0-0.1$ \\
Total & - & 02 & $0.11-0.30$ \\
\hline
\end{tabular}


Table 5. Grouping of NDV isolates and vaccine strains by ICPI and region

\begin{tabular}{|c|c|c|c|c|c|}
\hline \multirow{2}{*}{ Group } & \multirow{2}{*}{ Range of ICPI } & \multicolumn{2}{|c|}{ NDV isolates } & \multirow{2}{*}{ Region \% } & \multirow{2}{*}{ Vaccine strains } \\
\hline & & $\mathbf{N}$ & $\%$ & & \\
\hline (1) & 0.00 to 0.10 & 32 & 41.5 & $\begin{array}{c}68.7 \mathrm{ST} \\
25.0 \mathrm{~S} \\
6.3 \mathrm{CW}\end{array}$ & Ulster, VG-GA, V4, C2 \\
\hline (2) & 0.11 to 0.30 & 27 & 35.1 & $\begin{array}{c}46.1 \mathrm{ST} \\
44.4 \mathrm{~S} \\
7.4 \mathrm{CW}\end{array}$ & $\mathrm{B}_{1}$ \\
\hline (3) & 0.31 to 0.50 & 14 & 18.2 & $\begin{array}{c}50.0 \mathrm{ST} \\
42.9 \mathrm{~S} \\
7.1 \mathrm{CW}\end{array}$ & La Sota, Clone 30 \\
\hline (4) & 0.51 to 0.66 & 04 & 5.2 & $\begin{array}{c}75.0 \mathrm{ST} \\
25.0 \mathrm{~S}\end{array}$ & Other virus \\
\hline
\end{tabular}

$\mathrm{ST}=$ Southeastern $\mathrm{S}=$ Southern $\mathrm{CW}=$ Central-Western

Table 6. Percentage of NDV isolates by state

\begin{tabular}{ccccc}
\hline State & $\begin{array}{c}\text { Number of flocks } \\
\text { surveyed }\end{array}$ & NDV/flock \% & \multicolumn{2}{c}{ NDV isolates } \\
Minas Gerais & 206 & 5.3 & 11 & n \\
São Paulo & 386 & 8.8 & 34 & 44.3 \\
Paraná & 190 & 7.9 & 15 & 19.5 \\
Santa Catarina & 171 & 4,7 & 08 & 10.4 \\
Rio Grande do Sul & 141 & 2.8 & 04 & 5.2 \\
Mato Grosso do Sul & 226 & 1,8 & 04 & 5,2 \\
Mato Grosso & 98 & 1.0 & 01 & 1.3 \\
Goiás & 108 & 0 & 0 & 0 \\
Distrito Federal & 57 & 0 & 0 & 0 \\
\hline
\end{tabular}

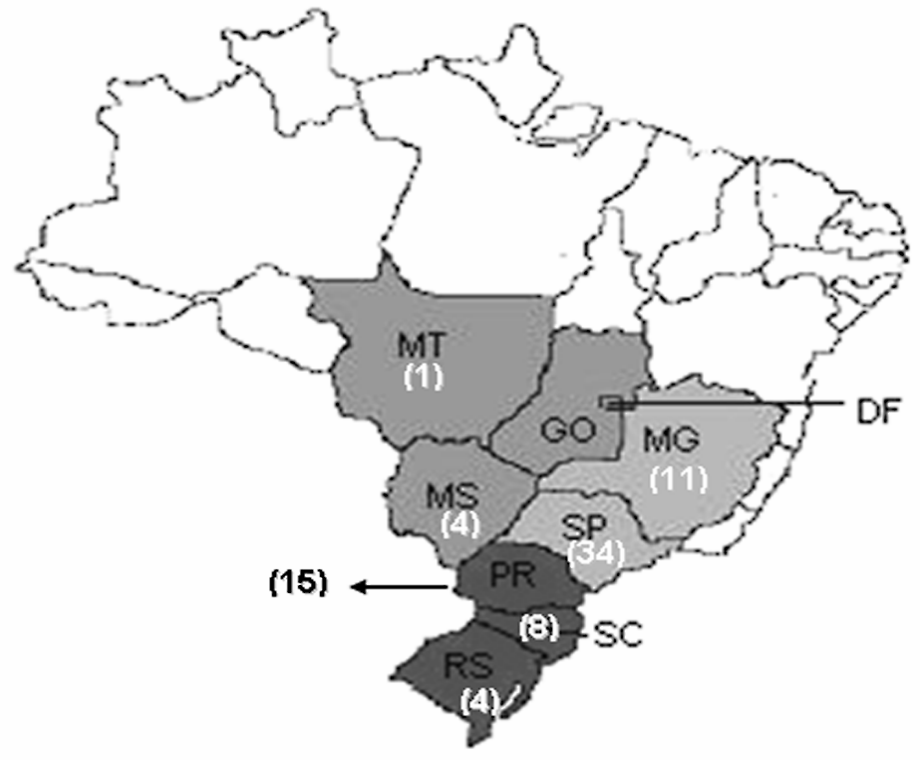

Figure1. Number of Newcastle Disease Virus isolates according to the state (number of isolates in white). 


\section{DISCUSSION}

The main objective of the present study was to investigate the presence of NDV in commercial healthy birds in the most important geographic areas for Brazilian poultry production and export. Birds vaccination efficacy can be monitored by means of serological tests (18) and a number of serological techniques can be used to detect specific antibodies to NDV. The haemagglutination inhibition (HI) test is the method of choice, but in recent years, several enzyme-linked immunosorbent assays (ELISA) were developed (16,30). Many studies on the sensitivity, specificity and correlation between $\mathrm{HI}$ test and ELISA indicate that results may not agree $(9,17,28)$. Commercially available NDV antibody ELISA kits are more sensitive than the $\mathrm{HI}$ test and, for diagnostic laboratories, the major advantages of ELISA kits are the assay standardization, the enhanced effectiveness due to semiautomation, and the speed for rapid screening for multiples agents (26).

The percentages of positive samples detected by ELISA were $66.4 \%, 23.3 \%$ and $22.3 \%$ in Southeastern, CentralWestern and Southern regions, respectively. These results confirm that poultry in the Southeastern region is vaccinated and that in Minas Gerais and São Paulo states and the northern region of Paraná state all categories of commercial birds are vaccinated against Newcastle disease, including broiler chickens, explaining the large number of sample serology reagents of this disease in these states. In addition, these results suggest virus movement from one region to others where no information on vaccination is available. This movement may be a consequence of the high density of birds in some regions, proximity to other species of birds, and also the coexistence of subsistence farms, side-by-side to well developed poultry husbandry.

ND vaccination in broiler chicken is not a practice in the states of Rio Grande do Sul, Santa Catarina, Mato Grosso, Mato Grosso do Sul, Goiás and the Federal District. However, in these states, birds for long life purposes, such as reproduction or egg production, are vaccinated. The vaccine selling maps available in the vaccine producing laboratories (data not shown), and the amount of vaccines sold for veterinary stores during the sampling period suggest that vaccination of broiler chickens was done, including nonindustrial husbandry exploration and subsistence birds.

In this study, the frequency of NDV in healthy birds varied from 1.0 to $7.6 \%$ per flocks, varying from $6.5 \%$ to $58.4 \%$ according to the geographic region. The isolation was higher in regions where vaccination is widely used, confirming results reported by Alexander (3), who observed that vaccine protects birds from clinical disease where virus replication and excretion may occur, even though in low levels. Kapcyznski et al., (12), studying exotic Newcastle disease (END) viruses that caused a major outbreak among commercial and backyard poultry in California (USA), observed that vaccines protected chickens against morbidity and mortality and significantly reduced the incidence and viral titers shed from chickens in comparison with sham controls, but did not prevent infection and virus shedding. Vaccinated commercial broilers exhibited $66 \%$ mortality and shed significantly more virus than broiler breeders.

A serological study was also conducted in Benin-Africa, in three different regions (Southern, Central and Northern regions), and $56 \%, 75 \%$ and $69 \%$ of the chickens were seropositive, respectively, $(6,7)$. The African results were similar to those obtained in this work. The presence of virus already in the first week of life of the birds, observed in the most regions due to litter reuse, led to the stimulation of the immune system

The highest virus isolation was observed in Southeastern region, followed by Southern and Central-Western regions. This is the first report indicating presence of NDV in regions where vaccinal status is not informed. Results also indicated a higher virus circulation in Southern region than in CentralWestern region. The high number of vaccination reported in the Southeastern region certainly correlates with the high number of isolates in the area. Similar prevalence, between 5 and $29 \%$, was found in one small chicken flock and purebred poultry flocks In Switzerland (25). 
Seropositivity and virus isolation in states with no vaccination against ND in broiler chickens can be explained by the high density of birds in some regions, the proximity with distinct categories of birds, and the coexistence of subsistence and low-technology farms along with highly technified poultry farms.

A better viral isolation was reached when samples were submitted to three passages in embryonated eggs. Contradictorily, Kouwenhoven (13) observed that $85 \%$ of the positive samples were positive in the $1^{\text {st }}$ passage and that only $10 \%$ needed a second blind passage. In exceptional cases, three blind passages were needed. The nature of the sample plays an important role in these tests. The two main sites of NDV replication in infected poultry appear to be the respiratory and intestinal tracts; therefore, specimens should always include cloacal and tracheal swabs (3). As pools from both tracheal and cloacal samples were taken from healthy birds with no sign of the disease, it is possible that some harvests occurred during a period of very small elimination of the virus. This may be observed by the low number of isolations in the first and second passages. In most samples, the embryos were not killed in the initial two passages and no lesions were observed, which could be due to low virus content of the inoculum. Therefore, a third passage seems to be necessary for virus adaptation to embryonated eggs.

In $94.8 \%$ of the isolates, the ICPI varied from 0.0 to 0.50 , which is the range where the Ulster $2 \mathrm{C}$, V4 Queensland, B1 and La Sota vaccine strains are located (4). This explained by the fact that the most frequently used vaccines in Brazil are $\mathrm{La}$ Sota and B1 (21). Based on these results, the isolated NDV strains can be classified as avirulent (lentogenic), although the virus genome has not been sequenced yet.

The isolation of virus with ICPI varying from 0.51 to 0.66 indicates the circulation of non-virulent/apathogenic strains in regions where vaccination status was not informed.

Yongolo (31) found similar results as the author also isolated lentogenic strains from healthy carrier birds.

The results in the present study show that the industrial poultry produced in the nine studied Brazilian states is free of
Newcastle disease, which is in accordance to requirements of the International Animal Health Code.

\section{ACKNOWLEDGEMENTS}

Authors are grateful to the Brazilian Ministry of Agriculture for providing financial and technical resources and authorization for the publication of this paper. The authors also thank Lanagro/SP, in particular the civil servants at the Poultry Disease Sector and Administration Sectors (computer assistance). Cleide A. M. Silva and Andrea F. Semolini (FCM/Unicamp) for their statistical support. C.W.A. and F.R.S. acknowledge the support from $\mathrm{CNPq}$ (National Council of Scientific and Technological Development, Brazil).

\section{REFERENCES}

1. ABEF- Associação Brasileira dos Produtores e Exportadores de Frangos. (2005). Relatório Anual

2. ABEF- Associação Brasileira dos Produtores e Exportadores de Frangos, (2006). Relatório Anual.

3. Alexander, D.J.; Gough, R.E. (2003).Newcastle disease other avian paramyxoviruses, and avian pneumovirus infection. In: Y.M.Saif, H.J. Barnes, A.M. Fadly, J. R. Glisson, L.R. McDougald \& D.E. Swayne (Eds), Diseases of poultry $11^{\text {th }}$, Ames, IA: Iowa State University Press, p.63-99.

4. Allan, W.H.; Lancaster, J.E.; Toth, B. (1978). Newcastle disease vaccines-Their production and use FAO Animal Production and Health Series $N^{\circ}$. 10. FAO: Rome, Italy.

5. BRASIL - Portaria Ministerial $\mathrm{n}^{\circ} 182$, de 8 de novembro de 1994. Aprova as normas de credenciamento e monitoramento de laboratórios de diagnóstico da doença de Newcastle. Diário Oficial da República do Brasil, Brasília, DF.

6. Bell, J.G. (1991). Vaccination of Africa village poultry against Newcastle disease. In: Demey and Pandey, V.S.(eds.)., Newcastle disease vaccination of village poultry in Africa and Asia. Proceedings of the seminar held on 13-14 February, Antwerp, p.3-8.

7. Bell, J.G. (1992). Newcastle disease in village chickens in North, West and Central Africa. In: Spradbrow P.B. Ed., Newcastle Disease in Village chickens, Control with Thermostable Oral vaccines, Proceedings, International Workshop held in Kaula Lumpur, Malaysia, 6-10 October, 1991. Centre for International Agriculture Research ACIAR, Canberra, p.142-143.

8. Bennejean, G. (1988). Newcastle disease: Control policies. In D.J. Alexander (ed). Newcastle Disease. Kluwer academic Publisher: Boston, MA, 303-317. 
9. Cvelic-Cabrilo, V.; Mazija, H.; Bindin, Z.; Ragland, W.L. (1992). Correlation of haemagglutination inhibition and enzyme-linked immunosorbent assays for antibodies to Newcastle disease virus. Avian Pathol. (21),509-512.

10. Cunha, R.G.; Silva, R.A. (1955).Isolamento e identificação do vírus da doença de Newcastle no Brasil. Soc. Bras. Med Vet. (23)17-33.

11. Fleiss, J.L. (1981). Statistical Methods for Rates and Proportions. $2^{\mathrm{a}}$ ed. John Wiley \& Sons Inc. Nova Iorque.

12. Kaczynski, D.R.; King, D.J. (2005). Protection of chickens against overt clinical disease and determination of viral shedding following vaccination with commercially available Newcastle disease virus vaccines upon challenge with highly virulent virus from the California 2002 exotic Newcastle disease outbreak. 2005. Vaccine 23 (26), 34243433.

13. Kouwenhoven, B. (1993). Newcastle disease. Virus Infections of Birds In: McFerran, J.B.; McNulty, M.S. Elsevier, chapter 23, p.350.

14. Mayo, M.A. (2002a). Virus taxonomy-Houston 2002. Arch. Virol.147, 1071-76.

15. Mayo, M.A. (2002b). A summary of taxonomic changes recently approved by ICTV. Arch Virol.(147),1655-1656.

16. Miers. L.A.; Bankowski, R.A.; Zee, Y.C. (1983). Optimizing the enzyme-linked immunosorbent assay for evaluating immunity in chickens to Newcastle disease. Avian Dis. 27,1112-1125.

17. Meulemans. G.; Carlier, M.C.; Gonze, M.; Petit, P.; Halen, P. (1984). Diagnostic serologique de la maladie de Newcastle par les tests d'inhibition de 1'hemagglutination et Elisa. Zetralbl Veterinaermed (B) 31:690-700.

18. Office International des Epizooties. (2007). Terrestrial Animal Health Standards Commission Report March 2007, APPENDIX 3.8.X.Guidelines on surveillance for Newcastle disease. Article 3.8.X.

19. Office International des Epizooties. (2000). Newcastle disease, p.221232. In Manual of standards for diagnostic tests and vaccines, 4th edition. World Organization for Animal Health, Paris, France.

20. Oliveira, B.O.; Belluci, M.S.P.; Portz, C.; Oliveira, J.R.J.G.; Doretto Jr, L.; Orsi, M.A.; Mazur, C.; Andrade, C.M. (2000). Biological characterization of M33 field isolate of Newcastle Disease virus. Virus Rev. Res. 05 (2), 56.

21. Orsi, M.A.; Doretto Jr., L.; Albieri, S.C.; Ribeiro, S.AM.; Yoshida, L.T. (2001). Quality control of live vaccines against Newcastle disease in the period 1993 to 2000. Virus Rev. Res., 06(2), 126

22. Santos, J.A. e col., (1954). A ocorrência da doença de Newcastle no Brasil. (Nota Previa). Rev. Prod Animal, (Rio),1 (1): 5-12.

23. SAS System for windows (Statistical Analysis System), versão 9.1.3 Service Pack 3. SAS Institute Inc, 2002-2003, Cary, NC, USA

24. Stram, Y.; Shchori, D.; Chinitch, Y.; David, D.; Molad, T.; Samina, I. (1998). Molecular characterization of an unassigned Israeli Newcastle disease virus isolate. Avian Dis. 42(4), 746-51.

25. Schelling, E.; Thur, B.; Griot, C.; Audige, L. (1999). Epidemiological study of Newcastle disease in backyard poultry and wild bird populations in Switzerland. Avian Pathol. 28(3), 263-272.

26. Snyder, D.B.; Marquardt, W.W.; Mallinson, E.T.; Saveage, P.K.; Allen, D.C. (1984). Rapid serological profiling by enzyme-linked immunosorbent assay. III Simultaneous measurements of antibody titers to infectious Bronchitis virus, infectious bursal disease and Newcastle disease virus in a single serum dilution. Avian Dis. 28,12-24.

27. Thayer, S.G.; Villegas, P.; Fletcher, O.J. (1987). Comparison of two commercial enzyme-linked immunosorbent assays and conventional methods for avian serology. Avian Dis. 31,120-124.

28. Vaitsman, J.; Moussatché, I. (1954). Doença de Newcastle. Boletim. 801 do Serviço de Informação Agrícola, Ministério da Agricultura, 56 p.

29. Vianna, J.S.M.; Mazur, C.; Portz, C.; Ferreira, I.I.; Almeida, C.A.S.; Galler, R. (2000). Identificação e caracterização biomolecular do vírus da doença de Newcastle pela técnica de RT-PCR. R. Bras. Med. Vet. 22,160-163.

30. Wilson, R.A.; Perrotta, C.; Frey, B.; Eckroade, R.J. (1984). An enzymelinked immunosorbent assay that measures protective antibody levels to Newcastle disease virus in chickens. Avian Dis. 28, 1079-1085.

31. Yongolo, M.G.S. (1996) Epidemiology of Newcastle Disease in Village Chickens in Tanzania. MVM. Dissertation, Sokoine University of Agriculture 230p. 